\title{
Somogy megye levélbogár és zsizsikfaunája (Coleoptera: Chrysomellidae, Bruchidae)
}

\author{
VIG KÁROLY
}

\begin{abstract}
VIG K.: The chrysomellid and seed beetle fauna of Somogy county (Coleoptera: Chrysomellidae, Bruchiidae)

Abstract: The earliest coleopterological records date back to the second half of the $19^{\text {th }}$ century. In spite of the diversity of habitats in this region, systematic faunistical surveys were not carried out until the last few decades of last century (in the Barcsi Landscape Protection Area and the Duna-Dráva National Park). The majority of the data available were the result of these faunistical surveys. Based only on the available literature, $27 \mathrm{l}$ chrysomelid taxa and 3 seed weevil species are known from the county.
\end{abstract}

\section{Bevezetés}

Hazánk faunájának tervszerú kutatása a múlt század második felében kezdôdött. A kutatómunka eredményei a század végére egy hatalmas, a maga korában egyedülálló tanulmánykötetté összegződtek: több részletben megjelent a Kárpát-medence egész területére kiterjedố faunisztikai ismereteinket bemutató mú, a Magyar Birodalom Állatvilága - Fauna Regni Hungariae, amely hosszú évtizedekre meghatározó kiindulási alapot jelentett bármilyen faunisztikai tevékenységhez.

Kikre támaszkodhatott a vállalkozás? Vajon bírhatta-e erôvel, idôvel a gyúités, a feldolgozás és a közzététel terheit a múzeumokban, egyetemeken dolgozó csekély számú zoológus kollektíva? Bár a kiegyezés utáni idôszak gazdasági fellendülése, társadalmi „békéje” a mai állapotokkal összevetve sokkal alkalmasabb légkört teremthetett az elmélyült kutatómunkához, feltett kérdéseinkre a válasz minden bizonnyal nem. A magyarság lélekszámához viszonyítva, a nálunknál solkkal nagyobb nemzetekhez képest is számos, nemzetközileg elismert zoológust adott a világnak. Elég említeni Frivaldszky Imre, Frivaldszky János, Petényi Salamon János, Herman Ottó, Chernel István, Madarász Gyula, Mocsáry Sándor, Szépligeti Győzô, Horváth Géza, Kertész Kálmán, Csiki Ernő és Bíró Lajos nevét. Ne feledjük el azonban, hogy e világnagyságok mellett, szerte az országban, a szó legnemesebb értelmében amatőr zoológusok, tanítók, orvosok, gyógyszerészek egyházi- és köztisztviselők népes tábora munkálkodott lakóhelye környéke élóvilágának megismerésében. A kor taxonómiai ismereti szintjén, illetve a rendelkezésre álló, a maguk nemében kitúnó határozó könyvek segítségével, a vidéki kúriák, tanári szobák csendjében és meghittségében naponta sokan hajoltak nagyítóüveggel, mikroszkóppal rovardobozok fölé, hogy az addig még nem látott példány tújére örömmel ráhúzhassák a faj latin nevét. Ha pedig a próbálkozás eredménytelen volt, a budapesti Természettudományi Múzeum szakemberei mindig tudtak idôt szakítani a beérkezett anyag megvizsgálására.

Az iskolai évkönyvek, értesítók, illetve a meginduló állattani szakfolyóiratok 
sok esetben jelentettek publikálási lehetőséget az eredmények számára, amelyek a legtöbb esetben egy-egy város, falu környékén megtalált állatfajok felsorolását jelentették.

Hol vannak ma vajon ezek a gyưjitemények, kicsinyke életmúvek? Századunk viharai alig egyet-kettôt hagytak meg az utókornak. A háborúk zúrzavara, a gondos kezek hiánya, a nemtörődömség, vagy a legtöbb esetben a hozzá nem értés következtében pusztultak el, semmisültek meg ezek a hazánk állatvilágának akkori gazdagságát dokumentáló gyújtemények. Így, sajnos, az eldugott, ma már szinte alig fellelhetô kiadványokban közzétett adatokat is csak kétkedve fogadja napjaink zoológus kutatója.

Magyarország területének megváltozása, illetve a taxonómiai-szisztematikai ismeretek gyarapodása szükségszerúen újabb, az ország egész területére kiterjedő, nagyszabású faunisztikai feltáró munkát hívott életre. Az ötvenes években indult útjára az a kutatási program, amelynek eredményei mind a mai napig újabb füzetekkel bővüló kiadványsorozatban láttak-látnak napvilágot. A Magyarország Állatvilága - Fauna Hungariae sorozat szerzôi Magyarország állatvilágának egyes taxonjait mutatják be, határozókulcsot is mellékelve az azonosításhoz.

A magyar faunakutatás harmadik szakaszát a természetvédelmi oltalom alatt álló területek élóvilágának megismerése jelentette. A Magyar Természettudományi Múzeum szakemberei elsősorban a nemzeti parkok állat- és növényvilágát, míg a vidéki múzeumokban dolgozó faunisták-floristák lakóhelyük tágabban értelmezett környéke élővilágát kutatták.

Tudománytörténeti szempontból érdekes tény, hogy Somogy megye területén egyetlen kivételtól eltekintve (PoLINszky 1886) nem születtek, vagy nem maradtak ránk olyan múvek, amelyek a megye bogárvilágával foglalkoztak volna; szemben a szomszédos Baranya, vagy Tolna megyével, ahol már a XIX. században jelentôs faunisztikai kutatások zajlottak, amelyek a XX. században fokozódó lendülettel folytak tovább.

$\mathrm{Az}$ 1850-es években Pécs környékén Viertl Béla cs. kir. vadász-százados gyúijtött bogarakat, majd a város bogárfaunáját 1894-ben, enumeráció formájában publikálta (VIERTL 1894). Halála után gyújteménye külföldre (Csehország) került. Meschnigg 1904 és 1908 között Sátorhelyen végzett koleopterológiai gyújtéseket, gyújteménye szintén külföldre vándorolt. Baranya megye bogarászati kutatásában meghatározó volt Kaufmann Ernő munkássága, figyelme elsősorban a Mecsekre és Pécs környékére irányult (KaUfMANN 1914a, 1914b). Kiemelendó Gebhardt Antal szerteágazó koleopterológiai tevékenysége is (pl. GEBHARDT 1965). A múlt század utolsó évtizedében a Baranya és Bács-Kiskun megyéhez tartozó Béda-Karapancsa Tájvédelmi Körzetben zajlott egy három éves kutatási program, viszonylag szerényebb eredményekkel (UHERKOVICH 1992).

Tolna megyében Pillich Ferenc gyógyszerész Simontornya környékén végzett florisztikai, faunisztikai vizsgálatokat, melyekből jelen tanulmányunk szempontjából rovartani munkáit emeljük ki (PILlich 1910-1911, 1912, 1914).

Somogy megyéből hasonló jellegú, a megye bogárvilágával foglalkozó korábbi vizsgálatokról, egyetlen kivételtől eltekintve (POLINSZKY 1886), alig van tudomásunk. Kivételként említhetjük Polinszky Emil és Lichtneckert Ferenc gyúijtôtevékenységét, az utóbbi azonban irodalmi munkásságot nem fejtett ki. A múlt század utolsó évtizedeiben a Dráva mente - beleértve a Barcsi Tájvédelmi Körzetet is - zoológiai kutatása mutathatott fel igen jelentôs eredményeket (UHERKOVICH 1978, 1981, 1983, 1985, 1995, 1998). 


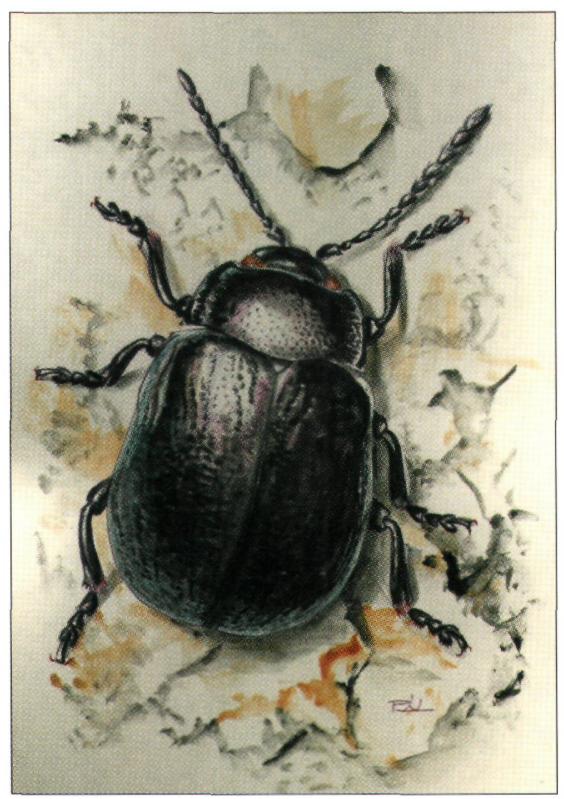

1. ábra: Chrysolina eurina

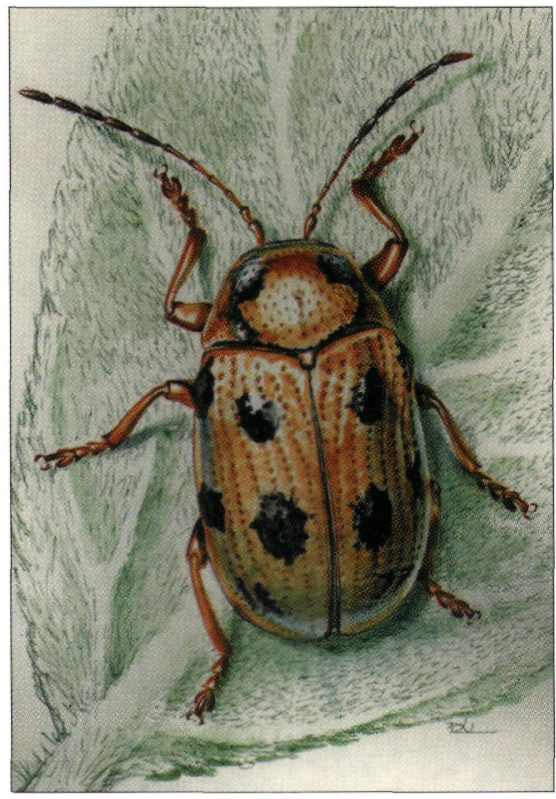

2. ábra: Cryptocephalus decemmaculatus 


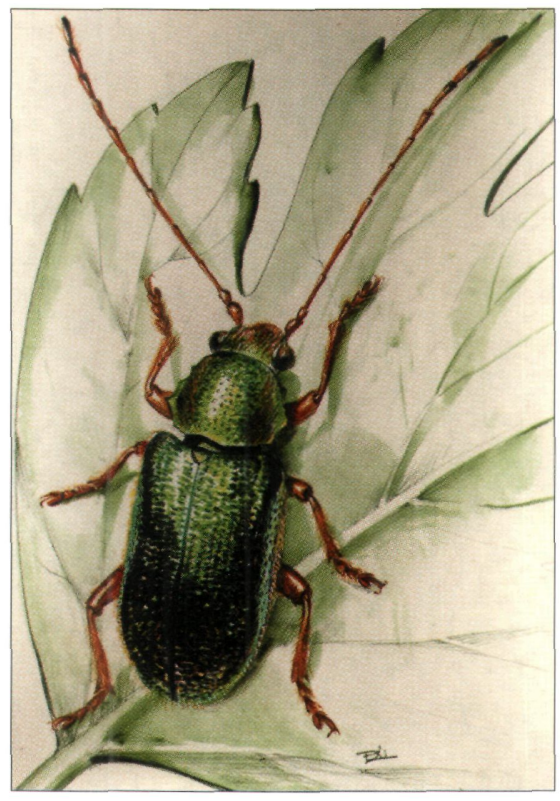

3. ábra: Pales ulema

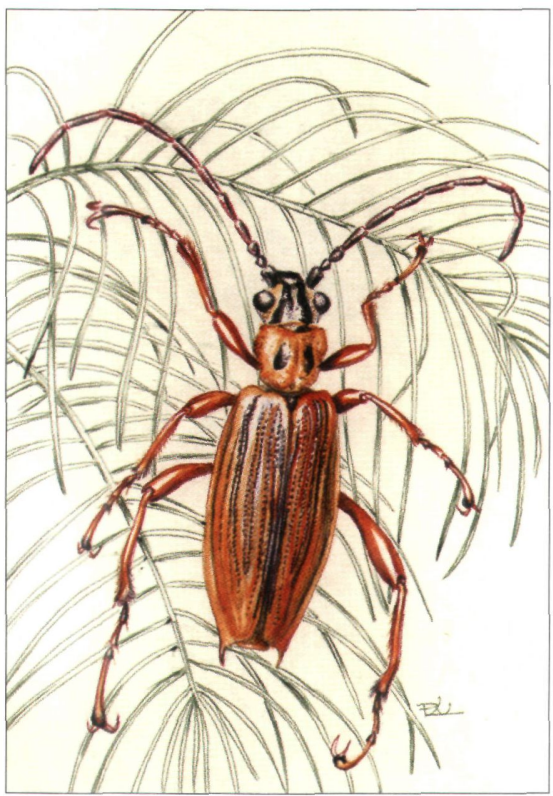

4. ábra: Macroplea mutica 


\section{Somogy megye levélbogár- és zsizsikfaunájáról rendelkezésre álló források}

A megye levélbogárfaunájáról publikált anyag viszonylag szerény, s az adatok zöme is a közelmúltban folytatott gyújtésekból származik. Hangsúlyoznunk kell, hogy jelen tanulmányban csak az irodalomban fellelhetô lelóhelyadatok szerepelnek, tehát a múzeumi gyújiteményekben ôrzött, Somogy megye területéről származó példányok nem kerültek említésre. A legelső, úttörő jellegú gyứjtéseket Polinszky Emil végezte a mai Balatonboglár (és Szigetvár) környékén. Eredményeit rövid lista formájában tette közzé (POLINSZKY 1886). A régebbi adatok szinte kizárólag a Magyar Birodalom Állatvilága - Fauna Regni Hungariae Coleoptera fejezetéból (KUTHY, 1897), illetve a Magyarország Állatvilága - Fauna Hungariae sorozat Levélbogarak - Chrysomelidae valamint Zsizsikfélék - Bruchidae kötetéból származnak (KASzAB 1962a, 1967). Az adatok zöme a közelmúltban, a Duna-Dráva Nemzeti Park területén végzett gyújtések és feldolgozás eredménye (VIG 1998a, MERKL 1998).

Az irodalomban található adatok közül a Magyarország Állatvilága - Fauna Hungariae sorozat Levélbogarak - Chrysomelidae kötetében (KASZAB 1962a; illetve KASZAB 1962b) előforduló Siófok lelőhellyel kapcsolatban a következöket kell megjegyeznünk. A Siófok lelőhelyről származó példányok Lichtneckert Ferenc gyújteményéból kerültek a Magyar Természettudományi Múzeum (Budapest) kollekciójába. A példányok egy részét maga Lichtneckert cédulázta, ezekkel kapcsolatban nincs okunk kételkedni, hogy azok valóban Siófok környékén kerültek begyúijtésre. Az anyag nagyobbik részét azonban Lichtneckert halála után, már a budapesti múzeumban látták el a Siófok lelöhelyet feltüntetố cédulával. A két cédula természetesen könnyedén megkülönböztethetố, de már Kaszab Zoltán sem tett különbséget közöttük (KASZAB 1962a, 1962b), így pusztán az irodalmi adatok alapján nem dönthetố el, hogy az adott példányt valóban Siófok környékén gyứjtötték-e. Ez a tény, illetve az adott faj eddig ismert elófordulási helyei, számos esetben megkérdőjelezik, hogy a példány Siófok mellól származik.

Tóth László számos munkájában (pl. TóTH 1979) hivatkozott Lichtneckert gyújtônaplójára, amely - a hivatkozások szerint - a birtokában volt. Sajnálatos, hogy sem a Bakonyi Természettudományi Múzeumban (Zirc), sem a Magyar Természettudományi Múzeumban (Budapest), ahová Tóth László hagyatéka került, nincs meg a gyüjtőnapló. Lichtneckert gyứjteménye szempontjából igen fontos esemény volna, ha a napló elókerülne, mert igen jelentốs számú példány lelóhelyét lehetne pontosítani.

Abban az idốben, amikor Kaszab Zoltán faunamunkája is készült, még nagy figyelmet fordítottak a változatok, varietas-ok, különbözó formák megkülönböztetésére és dokumentálá-sára. Napjainkra, a fajfogalom átalakulása következtében ezek a taxonómiai kategóriák - mint a fajon belüli változatosság megnyilvánulásai - nem bírnak olyan jelentôséggel. Ez a megál-lapítás azonban csak a zootaxonómiára érvényes, a botanikusok ma is kiemelt hangsúlyt fordítanak ezen mikrotaxonok megkülönböztetésére.

A történeti húség végett az enumeráció tartalmazza az irodalomban előforduló, faj alatti kate-góriákat is. 


\section{Rendszertani kérdések}

Napjainkban a levélbogarak családjának (Coleoptera: Chrysomelidae) rendszertani körülhatárolása, definíciója számos megoldásra váró kérdést vet fel. A problémát nehezíti, hogy a család belső felosztása körüli viták sem jutottak nyugvópontra.

Kladisztikai analízis segítségével, tradicionálisan a levélbogarak, illetve a zsizsikek (Coleoptera: Bruchidae) családjába sorolt alcsalád rangú taxonok új filogenetikai rendszerezé-se készült el (REID 1995). Az új elrendezés jelentốsen eltér a korábban hagyományosan követett felosztástól. Jelen munkámban a hagyományos felosztást követem, amelyet az Európában megjelenő faunisztikai irodalom is használ (KIPPENBERG \& DöBERL 1994).

\section{Somogy területéról kimutatott taxonok felsorlása}

\author{
Chrysomelidae \\ Orsodacninae \\ Orsodacne lineola (Panzer, 1795) - Darány \\ (Vig 1998a: 253); Potony (Vig 1998a: 253).
}

\author{
Zeugophorinae \\ Zeugophora subspinosa (Fabricius, 1781) - \\ Örtilos (Vig 1998a: 253).
}

\section{Donaciinae}

Macroplea mutica balatonica (Srśkessy, 1941) Zamárdi (Vig, 1996: 24).

Donacia antiqua Kunze, 1818 - Barcsi ósborókás (Vig 1998a: 253).

Donacia bicolor Zschach, 1788 - Barcsi ôsborókás (Vig 1998a: 253); Gyékényes: Lankócierdố (Vig 1998a: 253).

Donacia cinerea Herbst, 1784 - Barcsi ôsborókás (Vig 1998a: 253).

Donacia impressa Paykull, 1799 Drávatamási (Vig 1998a: 253).

Donacia marginata Hoppe, 1795 - Barcsi ôsborókás (Vig 1998a: 253).

Donacia semicuprea Panzer, 1796 - Barcsi ôsborókás (Vig I998a: 253); Bélavár (Vig 1998a: 253); Bolhó (Vig 1998a: 253).

Plateumaris sericea (Linnaeus, 1758) - Barcsi ósborókás (Vig 1998a: 253); Szenta (Vig 1998a: 253).

Plateumaris sericea ab. tenebricosa - Siófok (Kaszab, 1962a: 21).

Lema cyanella (Linnaeus, 1758) - Gyékényes (Vig 1998a: 253); Órtilos (Vig 1998a: 253).

Oulema gallaeciana (Heyden, 1870) - Barcsi ôsborókás (Vig 1998a: 253); Bélavár (Vig 1998a: 254); Darány (Vig 1998a: 254); Ôrtilos (Vig 1998a: 253); Vízvár (Vig 1998a: 254, 1998b).

Oulema melanopus (Linnaeus, 1758) Babócsa (Vig 1998b); Barcsi ôsborókás (Vig 1998a: 254); Bélavár (Vig 1998a: 254); Bolhó (Vig 1998a: 253); Darány (Vig 1998a: 254); Drávatamási (Vig 1998a: 254); Komlósd (Vig 1998a: 254); Órtilos (Vig 1998a: 254); Somogyudvarhely (Vig 1998a: 254); Vízvár (Vig 1998a: 254, 1998b).

Crioceris asparagi (Linnaeus, 1758) - Kaposvár (Kuthy 1896: I84), pontos lelóhely nélkül (Polinszky 1886: 148).

Crioceris duodecimpunctata (Linnaeus, 1758) Kaposvár (Kuthy 1896: 184).

Crioceris dwodecimpunctata ab. Augustodini Zamárdi (Kaszab, 1962a: 29, 1962b: 28).

Crioceris duodecimpunctata ab. Gisellae -

Zamárdi (Kaszab 1962a: 29, 1962b: 28). Crioceris duodecimpunctata ab. Gurányii Zamárdi (Kaszab 1962a: 30, 1962b: 28). Crioceris duodecimpunctata ab. Ruffi -

Zamárdi (Kaszab 1962a: 30, 1962b: 28). Crioceris duodecimpunctata ab. bisquadripunctata - Zamárdi (Kaszab 1962a: 30, 1962b: 28). Crioceris duodecimpunctata ab. dodecastigma -

Siófok (Kaszab 1962a: 29, 1962b: 29).

Crioceris quatuordecimpunctata (Scopoli, 1763) ab. Lichtneckerti - Siófok (Kaszab 1962a: 31, 1962b: 29), pontos lelóhely nélkül (Polinszky 1886: 148). Crioceris quinquepunctata (Scopoli, 1763) ab. thoracica - Siófok (Kaszab 1962a: 32).

Crioceris quinquepunctata ab. Kaufmanni - So- 
mogy megye (Kaszab 1962a: 32, 1962b: 31). Lilioceris merdigera (Linnaeus, 1758) - Örtilos (Vig 1998a: 254).

\section{Clytrinae}

Labidostomis cyanicornis Germar, 1817 Potony (Vig 1998a: 253).

Labidostomis longimana (Linnacus, 1761) Babócsa (Vig 1998b); Barcsi ősborókás (Vig 1998a: 254); Drávaszentes (Vig 1998a: 254); Bélavár (Vig 1998a: 254); Darány (Vig 1998a: 254); Gordisa (Vig 1998a: 254); Heresznye (Vig 1998b); Potony (Vig 1998a: 254); Vízvár (Vig 1998b).

Lachnaia sexpunctata (Scopoli, 1763) - Barcsi ôsborókás (Vig 1998a: 254).

Clytra laeviuscula Ratzeburg, 1837 - Barcsi ősborókás (Vig 1998a: 254); Bélavár (Vig 1998a: 254); Darány (Vig 1998a: 254); Kašzópuszta (Vig 1998a: 254); Örtilos (Vig 1998a: 254); Potony (Vig 1998a: 254).

Coptocephala rubicunda (Laicharting, 1781)

ab. connexa - Somogyapáti (Kaszab 1962a: 62).

Coptocephala rubicunda ab. pittata - Siófok (Kaszab 1962a: 62)

Coptocephala unifasciata (Scopoli, 1763) -

Barcs (Vig 1998a: 254); Barcsi ósborókás (Vig 1998a: 254); Darány (Vig 1998a: 254).

Coptocephala unifasciata ab. reducta - Öszöd (Kaszab 1962b: 32); Siófok (Kaszab 1962b: 32).

Smaragdina aurita (Linnaeus, 1767) - Bolhó (Vig 1998a: 254); Vízvár (Vig 1998a: 254).

Smaragdina flavicollis (Charpentier, 1825) -

Barcsi ósborókás (Vig 1998a: 254).

Smaragdina tibialis hungarica Weise, 1895 -

Siófok (Kaszab 1962a: 65, 1962b: 79).

Smaragdina salicina (Scopoli, 1763) -

Bélavár (Vig 1998a: 255); Heresznye (Vig 1998a: 255); Szenta (Vig 1998a: 255); Tótújfalu (Vig 1998a: 255).

Smaragdina xanthaspis (Germar, 1824) -

Vízvár (Vig 1998a: 255).

\section{Cryptocephalinae}

Pachybrachis hieroglyphicus (Laicharting, 1781) - Babócsa (Vig 1998a: 255); Bélavár (Vig 1998a: 255); Órtilos (Vig 1998a: 255); Vízvár (Vig 1998a: 255).

Pachybrachis sinuatus Mulsant, 1859 .

Bélavár (Vig 1998a: 255).

Cryptocephalus bilineatus (Linnaeus, 1767) -

Barcsi ösborókás (Vig 1998a: 255).

Cryptocephalus bilineatus ab. bakonyensis Siófok (Kaszab 1962a: 119, 1962b: 47).
Cryptocephalus bipunctatus (Linnaeus, 1758) Barcs (Vig 1998a: 255); Darány (Vig 1998a: 255). Cryptocephalus connexus Olivier, 1807 . Heresznye (Vig 1998b).

Cryptocephalus connexus ab. arenarius - Siófok (Kaszab 1962a: 127, 1962b: 53).

Cryptocephalus connexus ab. bisbireductellus -

Siófok (Kaszab 1962a: 127, 1962b: 51).

Cryptocephalus connexus ab. Lichtneckerti - Balaton környéke (Kaszab 1962a: 127); Öszöd (Kaszab 1962b: 53).

Cryptocephalus connexus ab. reductevittatus Siófok (Kaszab 1962a: 126, 1962b: 51).

Cryptocephalus connexus ab. Sajói - Siófok (Kaszab 1962a: 127, 1962b: 53).

Cryptocephalus cordiger (Linnaeus, 1758) ab. tihanyensis - Siófok (Kaszab 1962a: 86).

Cryptocephalus czwalinai Weise, 1882 - Siófok (Kaszab 1962a: 125, 1962b: 84).

Cryptocephalus decemmaculatus (Linnaeus, 1758) - Kaszópuszta (Vig 1998a: 255).

Cryptocephalus elegantulus Gravenhorst, 1807 - Barcsi ósborókás (Vig 1998a: 255).

Cryptocephalus flavipes Fabricius, 1781 Örtilos (Vig 1998a: 255); Tótúffalu (Vig 1998a: 255).

Cryptocephalus fulvus (Goeze, 1777) - Barcsi ôsborókás (Vig 1998a: 255); Darány (Vig 1998a: 255).

Cryptocephalus fulyus ab. signaticollis - Siófok (Kaszab 1962a: 128).

Cryptocephalus hypochaeridis hypochaeridis (Linnaeus, 1758) - Siófok (Kaszab 1962a: 96).

Cryptocephalus hypochaeridis transiens Franz, 1949 - Babócsa (Vig 1998b); Barcsi ósborókás (Vig 1998a: 255); Bélavár (Vig 1998a: 255); Darány (Vig 1998a: 255); Kaszópuszta (Vig 1998a: 255); Órtilos (Vig 1998a: 255); Potony (Vig 1998a: 255); Vízvár (Vig 1998b).

Cryptocephalus janthinus Germar, 1824 . Barcsi ôsborókás (Vig 1998a: 255).

Cryptocephalus janthinus ab. Satanas Balatonlelle (Kaszab 1962b: 46); Zamárdi (Kaszab 1962b: 46).

Cryptocephalus labiatus (Linnaeus, 1761) Babócsa (Vig 1998b); Barcsi ősborókás (Vig 1998a: 256); Vízvár (Vig 1998b).

Cryptocephalus laetus Fabricius, 1792 ab. balatonicus - Siófok (Kaszab 1962b: 45).

Cryptocephalus marginellus Olivier, 1791 Siófok (Kaszab 1962a: 100).

Cryptocephalus moraei (Linnaeus, 1758) Barcs (Vig 1998a: 255); Barcsi ósborókás (Vig I998a: 256); Bélavár (Vig 1998a: 256); Darány (Vig 1998a: 256); Kaszópuszta (Vig 
1998a: 256); Potony (Vig 1998a: 256); Szenta (Vig 1998a: 256).

Cryptocephalus nitidulus Fabricius, 1787 ab. stigmula - Öszöd (Kaszab 1962a: 99).

Cryptocephalus nitidus (Linnaeus, 1758) Barcs (Vig 1998a: 256); Barcsi ốsborókás (Vig 1998a: 256).

Cryptocephalus ocellatus Drapiez, 1819 Darány (Vig 1998a: 256); Órtilos (Vig 1998a: 256); Vízvár (Vig 1998a: 256).

Cryptocephalus ochroleucus Stephens, 1834 Siófok (Kaszab 1962a: 127); Zamárdi (Kaszab 1962a: 127).

Cryptocephalus octacosmus Bedel, 1891 Komlósd (Vig 1998a: 256); Potony (Vig 1998a: 256).

Cryptocephalus octomaculatus Rossi, $1790 \mathrm{ab}$. Birói - Öszöd (Kaszab 1962a: 92, 1962b: 43).

Cryptocephalus octomaculatus ab. cumanensis Kaposvár (Kaszab 1962b: 42).

Cryptocephalus octomaculatus ab. cumaniensis Kaposvár (Kaszab 1962a: 91).

Cryptocephalus octomaculatus ab. Hajóssi Öszöd (Kaszab 1962a: 9I, 1962b: 43).

Cryptocephalus octomaculatus ab. testaceus Öszöd (Kaszab 1962a: 90, 1962b: 42).

Cryptocephalus octopunctatus (Scopoli, 1763) ab. multiinterruptus - Siófok (Kaszab 1962a: 82, 1962b: 38).

Cryptocephalus pini (Linnaeus, 1758) -

Darány (Vig I998a: 256).

Cryptocephalus pusillus Fabricius, 1777 -

Babócsa (Vig 1998b); Barcsi ósborókás (Vig 1998a: 256); Darány (Vig 1998a: 256).

Cryptocephalus pusillus ab. flavissimus - Siófok (Kaszab 1962a: 13I).

Cryptocephalus pusillus ab. multinigronotatus Siófok (Kaszab 1962a: 131).

Cryptocephalus pygmaeus Fabricius, 1792 . Boglár [=Balatonboglár] (Kuthy 1896: 187).

Cryptocephalus pygmaeus ab. Pazsiczkyi - Siófok (Kaszab 1962a: 126, 1962b: 51).

Cryptocephalus sericeus sericeus (Linnaeus, 1758) - Barcs (Vig 1998a: 255); Barcsi ósborókás (Vig 1998a: 256); Darány (Vig 1998a: 256); Szenta (Vig 1998a: 256); Vizvár (Vig 1998a: 256).

Cryptocephalus strigosus Germar, 1823 Babócsa (Vig 1998b); Barcsi ôsborókás (Vig 1998a: 256).

Cryptocephalus violaceus Laicharting, 1781 Barcsi ösborókás (Vig 1998a: 256); Bélavár (Vig 1998a: 256); Darány (Vig 1998a: 256); Örtilos (Vig 1998a: 256).

\section{Lamprosomatinae}

Oomorphus concolor (Sturm, 1807) - Órtilos

(Vig 1998a: 256); Zákány (Vig 1998a: 256).

\section{Eumolpinae}

Pales ulema (Germar, 1813) - Somogy megye (Siófok) (Kaszab 1962a: 140).

Bromius obscurus (Linnaeus, 1758) v. vitis Kercseliget (Kuthy 1896: 188).

\section{Chrysomelinae}

Timarcha pratensis (Duftschmidt, 1825) Somogy megye (Kaszab 1962a: 147).

Timarcha rugulosa Herrich-Schäffer, 1838 Somogyi-dombvidék (Kaszab 1962a: 148).

Leptinotarsa decemlineata (Say, I 824) - Vízvár (Vig 1998a: 256).

Chrysomela carnifex (Fabricius, 1792) - Siófok (Kaszab 1962a: 169, 1962b: 54).

Chrysolina eurina (Frivaldszky, 1883) - Órtilos (Vig I998a: 257); Vízvár (Vig 1998a: 257). Chrysolina fastuosa (Scopoli, 1763) Babócsa (Vig 1998a: 257); Barcsi ósborókás (Vig 1998a: 257); Bélavár (Vig 1998a: 257); Bolhó (Vig 1998a: 257); Drávatamási (Vig 1998a: 257); Gyékényes (Vig 1998a: 257); Heresznye (Vig 1998a: 257); Kaszópuszta (Vig 1998a: 257); Örtilos (Vig 1998a: 257); Somogyudvarhely (Vig 1998a: 257); Szenta (Vig 1998a: 257); Vízvár (Vig 1998a: 257); Zákány (Vig 1998a: 257).

Chrysolina fastuosa ab. rugosicollis - Siófok (Kaszab 1962a: 185).

Chrysolina graminis (Linnaeus, 1758). Babócsa (Vig 1998b); Barcsi ósborókás (Vig 1998a: 257); Darány (Vig 1998a: 257); Gyékényes (Vig 1998a: 257); Kaszópuszta (Vig 1998a: 257); Örtilos (Vig I998a: 257); Somogyudvarhely (Vig 1998a: 257).

Chrysolina haemoptera (Linnaeus, 1758) pontos lelóhely nélkül (Polinszky 1886: 148).

Chrysolina herbacea (Duftschmidt, 1825) -

Babócsa (Vig 1998b); Barcsi ősborókás (Vig 1998a: 257); Bélavár (Vig 1998a: 257); Darány (Vig 1998a: 257); Drávatamási (Vig 1998a: 257); Gyékényes (Vig 1998a: 257); Potony (Vig 1998a: 257); Vízvár (Vig 1998a: 257).

Chrysomela hemisphaerica purpurascens (Germar, 1882) - Siófok (Kaszab 1962a: 166).

Chrysolina hyperici (Forster, 1771) - Barcs (Vig 1998a: 257); Barcsi ósborókás (Vig 1998a: 257); Darány (Vig 1998a: 257); Vízvár (Vig 1998b).

Chrysolina limbata (Fabricius, 1775) - Barcsi ősborókás (Vig 1998a: 257); Darány (Vig 
I998a: 257); Kaszópuszta (Vig 1998a: 257).

Chrysolina polita (Linnaeus, 1758) - Barcsi ósborókás (Vig 1998a: 257); Bélavár (Vig 1998a: 257); Darány (Vig 1998a: 257); Szenta (Vig 1998a: 257); Vízvár (Vig 1998a: 257).

Chrysolina staphylaea (Linnaeus, 1758) -

Darány (Vig 1998a: 258).

Chrysolina sturmi (Westhoff, 1882) - Barcsi ósborókás (Vig 1998a: 258); Gyékényes (Vig 1998a: 258); Szenta (Vig 1998a: 258).

Chrysolina varians (Schaller, I783) Babócsa (Vig 1998b); Barcsi ósborókás (Vig 1998a: 258); Darány (Vig 1998a: 258); Vízvár (Vig 1998b).

Gastrophysa polygoni (Linnaeus, 1758) - Barcsi ôsborókás (Vig 1998a: 258); Vízvár (Vig 1998a: 258).

Gastrophysa piridula (De Geer, 1775) Bélavár (Vig 1998a: 258); Drávatamási (Vig 1998a: 258); Gyékényes (Vig 1998a: 258); Órtilos (Vig 1998a: 258); Vízvár (Vig 1998a: 258). Plagiodera versicolora (Laicharting, 1781). Bélavár (Vig 1998a: 258); Darány (Vig 1998a: 258); Ôrtilos (Vig 1998a: 258); Vízvár (Vig 1998a: 258).

Linnaeidea aenea (Linnaeus, 1758) - Barcsi ősborókás (Vig 1998a: 258); Bélavár (Vig 1998a: 258); Darány (Vig 1998a: 258).

Chrysomela cuprea Fabricius, 1775 Somogyudvarhely (Vig 1998a: 258).

Chrysomela populi Linnaeus, 1758 - Barcs (Vig 1998a: 258); Barcsi ósborókás (Vig 1998a: 258); Darány (Vig 1998a: 258); Drávatamási (Vig 1998a: 258); Gyékényes (Vig 1998a: 258); Örtilos (Vig 1998a: 258).

Chrysomela saliceti (Weise, 1884) - Vízvár (Vig 1998a: 258).

Chrysomela vigintipunctata (Scopoli, 1763) -

Somogyudvarhely (Vig I998a: 259).

Hydrothassa flavocincta (Brullé, 1832) - Sió-

fok (Kaszab 1962b: 85).

Hydrothassa marginella (Linnaeus, 1758) -

Barcsi ősborókás (Vig 1998a: 259); Bélavár (Vig 1998a: 259); Órtilos (Vig 1998a: 259);

Szenta (Vig 1998a: 259).

Prasocuris phellandrii (Linnaeus, 1758) -

Örtilos (Vig 1998a: 259); Szenta (Vig 1998a: 259).

Timarchida deubeli Ganglbauer, 1897 - Sió-

fok (Kaszab 1962a: 210).

Phaedon cochlaeriae (Fabricius, 1792) - Barcsi ósborókás (Vig 1998a: 259).

Phaedon laevigatus (Duftschmidt, 1825) Barcsi ősborókás (Vig 1998a: 259); Bélavár (Vig 1998a: 259); Bolhó (Vig 1998a: 259); Órtilos (Vig 1998a: 259).
Gonioctena decemnotata (Marsham,1802) Siófok (Kaszab 1962b: 57).

Gonioctena fornicata (Brüggemann, 1873) ab. nigriceps - Siófok (Kaszab 1962a: 224, 1962b: 66).

Gonioctena fornicata ab. Bohumilae - Siófok (Kaszab 1962a: 226, 1962b: 68).

Gonioctena interposita (Franz et Palmén, 1950) - Siófok (Kaszab 1962a: 228, 1962b: 86).

Gonioctena olivacea (Forster, 1771) ab. umbriceps - Balatonboglár (Kaszab 1962a: 227).

Phratora tibialis (Suffrian, 1851) - Örtilos (Vig 1998a: 259); Siófok (Kaszab 1962a: 231).

Phratora vitellinae (Linnaeus, 1758) - Barcs (Vig 1998a: 259); Barcsi ósborókás (Vig 1998a: 259).

Phratora pulgatissima (Linnaeus, 1758) Barcsi ôsborókás (Vig 1998a: 259).

\section{Galerucinae}

Xanthogaleruca luteola (Müller, 1766) Potony (Vig 1998a: 259).

Galerucella calmariensis (Linnaeus, 1767) Barcsi ösborókás (Vig 1998a: 259); Ôrtilos (Vig 1998a: 259); Vízvár (Vig 1998a: 259).

Galerucella lineola (Fabricius, 1781) - Barcsi ósborókás (Vig 1998a: 259); Bélavár (Vig 1998a: 259); Darány (Vig 1998a: 259); Gyékényes (Vig 1998a: 259); Órtilos (Vig 1998a: 259); Vízvár (Vig 1998a: 259).

Galerucella nymphaeae (Linnaeus, 1758) Barcsi ôsborókás (Vig 1998a: 259).

Galerucella pusilla (Duftschmidt, 1825) Heresznye (Vig 1998a: 260); Órtilos (Vig 1998a: 260).

Pyrrhalta piburni (Paykull, 1799) - Vízvár (Vig 1998a: 260).

Lochmaea capreae (Linnaeus, 1758) - Barcsi ősborókás (Vig 1998a: 260).

Lochmaea crataegi (Forster, 1771) ab. orientalis - Öszöd (Kaszab 1962a: 243); Vízvár (Vig 1998b).

Galeruca melanocephala (Ponza, 1805) Darány (Vig 1998a: 260).

Galeruca pomonae (Scopoli, 1763) - Barcsi ôsborókás (Vig 1998a: 260); Darány (Vig 1998a: 260).

Galeruca tanaceti (Linnaeus, 1758) - Barcs (Vig 1998a: 260); Barcsi ósborókás (Vig 1998a: 260); Darány (Vig 1998a: 260); Potony (Vig 1998a: 260); Vízvár (Vig 1998a: 260).

Phyllobrotica quadrimaculata (Linnaeus, 1758) - Barcsi ósborókás (Vig 1998a: 260); Darány (Vig 1998a: 260). 
Luperus xanthopoda (Schrank, 1781) Darány (Vig 1998a: 260); Ốrtilos (Vig 1998a: 260); Somogyudvarhely (Vig 1998a: 260); Tótújfalu (Vig I998a: 260).

Luperus viridipennis Germar, 1824 - Siófok (Kaszab 1962a: 254).

Luperus carniolicus Kiesenwetter, 1861 - Siófok (Kaszab 1962a: 255).

Agelastica alni (Linnaeus, 1758) - Barcs (Vig 1998a: 260); Barcsi ősborókás (Vig 1998a: 260); Darány (Vig 1998a: 260); Drávaszentes (Vig 1998a: 260); Drávatamási (Vig 1998a: 260); Heresznye (Vig 1998a: 260); Órtilos (Vig 1998a: 260); Szenta (Vig 1998a: 260).

\section{Alticinae}

Phyllotreta armoraciae (Koch, 1803) - Siófok (Vig, 1989: 60).

Phyllotreta astrachanica Lopatin, 1977 - Barcsi ósborókás (Vig 1998a: 260); Iharosberény (Vig 1998a: 260); Szenta (Vig 1998a: 260).

Phyllotreta atra (Fabricius, 1775) - Tótúffalu (Vig 1998a: 260).

Phyllotreta balcanica Heikertinger, 1909. Zamárdi (Kaszab 1962a: 277, 1962b: 88).

Phyllotreta christinae Heikertinger, 1941 .

Zamárdi (Kaszab 1962a: 268; Kaszab 1962b: 87).

Phyllotreta cruciferae (Goeze, 1777) - Barcs

(Vig 1998a: 261); Barcsi ósborókás (Vig 1998a: 261); Gyékényes (Vig 1998a: 261); Tótújfalu (Vig 1998a: 261); Vízvár (Vig 1998b).

Phyllotreta exclamationis (Thunberg, 1784) -

Szenta (Vig 1998a: 261).

Phyllotreta flexuosa (Illiger, 1794) - Siófok (Kaszab 1962a: 271).

Phyllotreta ochripes (Curtis, 1837) - Barcsi ősborókás (Vig 1998a: 261); Boglár [=Balatonboglár] (Kuthy 1896: 196); Siófok (Kaszab 1962a: 270); Zákány (Kuthy 1896: 196).

Phyllotreta striolata (Fabricius, 1803) Iharosberény (Vig 1998a: 261).

Phyllotreta tetrastigma (Comolli, 1837) ab.

Weiseana - Öszöd (Kaszab 1962a: 273); Őrtilos (Vig 1998a: 261).

Phyllotreta undulata Kutschera, 1860 - Barcsi ósborókás (Vig 1998a: 261); Darány (Vig 1998a: 261); Vízvár (Vig 1998b).

Phyllotreta vittula (Redtenbacher, 1849) Babócsa (Vig 1998b); Barcsi ôsborókás (Vig 1998a: 261); Darány (Vig 1998a: 261); Gyékényes (Vig 1998a: 261); Heresznye (Vig 1998b); Órtilos (Vig 1998a: 261); Szenta (Vig 1998a: 261); Vízvár (Vig 1998b).

Aphtona abdominalis (Duftschmidt, 1825) . Siófok (Kaszab 1962a: 282).
Aphtona atrocaerulea (Stephens, 1831) - Bog-

lár [=Balatonboglár] (Kuthy 1896: 197)

Aphtona cyparissiae (Koch, 1803) - Barcsi ôsborókás (Vig 1998a: 261).

Aphtona euphorbiae (Schrank, 1781) . Babócsa (Vig 1998b); Barcsi ôsborókás (Vig I998a: 261); Darány (Vig 1998a: 261).

Aphtona flava Guillebeau, 1894 - Barcs (Vig 1998a: 261); Darány (Vig 1998a: 261); Somogyi-dombvidék (Kaszab 1962a: 282).

Aphtona lutescens (Gyllenhal, 1808) - Barcsi ósborókás (Vig 1998a: 262); Bélavár (Vig 1998a: 262); Darány (Vig 1998a: 262); Szenta (Vig 1998a: 262).

Aphtona nigriscutis Foudras, 1860 - Barcs (Vig 1998a: 262); Barcsi ôsborókás (Vig 1998a: 262); Darány (Vig 1998a: 262).

Aphtona nonstriata (Goeze, 1777) - Barcsi ôsborókás (Vig 1998a: 261); Bélavár (Vig I998a: 261); Darány (Vig 1998a: 261).

Aphtona penustula (Kutschera, 1861) Iharosberény (Vig 1998a: 262); Vízvár (Vig 1998b).

Aphtona violacea (Koch, 1803) - Heresznye (Vig 1998b); Vízvár (Vig 1998b).

Longitarsus anchusae (Paykull, 1799) Babócsa (Vig 1998b).

Longitarsus bertii Leonardi, 1973 - Barcsi ôsborókás (Vig 1998a: 262).

Longitarsus brisouti Heikertinger, 1912 - Somogyi-dombvidék (Siófok) (Kaszab 1962a: 309, 1962b: 89).

Longitarsus cerinthes (Schrank,1798) - Siófok (Kaszab 1962a: 301).

Longitarsus curtus (Allard, 1860) ab. Lichtneckerti - Siófok (Kaszab 1962a: 311, 1962b: 73).

Longitarsus fulgens (Foudras, 1860) ab. exhaustus - Siófok (Kaszab 1962a: 316, 1962b: 89).

Longitarsus fuscoaeneus Redtenbacher, 1849 Siófok (Kaszab 1962a: 326).

Longitarsus ganglbaueri Heikertinger, 1912 -

Siófok (Kaszab 1962a: 308, 1962b: 88).

Longitarsus lateripunctatus personatus Weise, 1893 - Iharosberény (Vig 1998a: 262); Siófok (Kaszab 1962a: 314).

Longitarsus lewisii (Baly, 1874) - Siófok

(Gruev \& Merkl, 1992).

Longitarsus longipennis Kutschera, 1863 -

Babócsa (Vig 1998b).

Longitarsus longiseta Weise, 1889 - Vízvár (Vig 1998b).

Longitarsus luridus (Scopoli, 1763) -

Babócsa (Vig 1998b); Barcsi ósborókás (Vig 1998a: 262); Bélavár (Vig 1998a: 262); 
Tótújfalu (Vig 1998a: 262).

Longitarsus lycopi (Foudras, 1860) - Babócsa (Vig 1998b); Barcsi ősborókás (Vig 1998a: 262); Órtilos (Vig 1998a: 262); Szenta (Vig 1998a: 262).

Longitarsus melanocephalus (De Geer, 1775) Babócsa (Vig 1998b); Barcs (Vig 1998a: 262); Barcsi ősborókás (Vig 1998a: 262); Bélavár (Vig 1998a: 262); Potony (Vig 1998a: 262); Szenta (Vig 1998a: 262); Vízvár (Vig 1998a: 262).

Longitarsus melanocephalus ab. nigrosuturalis Siófok (Kaszab 1962a: 307).

Longitarsus minusculus (Foudras, 1860) Siófok (Kaszab 1962a: 315); Zamárdi (Kaszab 1962a: 315).

Longitarsus nasturtii (Fabricius, 1792) Darány (Vig 1998a: 262).

Longitarsus niger (Koch, 1803 ) ab. Peregii Kaposvár (Kaszab 1962a: 324); Kaposfüred (Kaszab 1962b: 74).

Longitarsus nigrofasciatus (Goeze, 1777) Gyékényes (Vig 1998a: 262).

Longitarsus parvulus (Paykull, 1799) Babócsa (Vig 1998b); Barcsi ősborókás (Vig 1998a: 262); Boglár [=Balatonboglár] (Kuthy 1896: 197); Iharosberény (Vig 1998a: 262).

Longitarsus pellucidus (Foudras, 1860) - Barcsi ősborókás (Vig 1998a: 262).

Longitarsus pratensis (Panzer, 1794) Balatonlelle (Gruev \& Merkl, 1992); Bélavár (Vig 1998a: 262); Bőszénfa (Gruev \& Merkl, 1992); Heresznye (Vig 1998b); pontos lelőhely nélkül (Polinszky 1886: 148).

Longitarsus quadriguttatus (Pontoppidan, 1765) ab. binotatus - Siófok (Kaszab 1962a: 320).

Longitarsus quadriguttatus ab. immaculatus Siófok (Kaszab 1962a: 320).

Longitarsus rectilineatus (Foudras, 1860) Somogyi-dombvidék (Balatonlelle) (Kaszab 1962a: 323).

Longitarsus reichei (Allard, 1860) - Siófok (Gruev \& Merkl, 1992).

Longitarsus scutellaris (Rey, 1874) - Kaposvár (Kaszab 1962a: 310); Siófok (Kaszab 1962a: 310; Gruev \& Merkl, 1992); Vízvár (Vig 1998b).

Longitarsus substriatus Kutschera, 1863 Gyékényes (Vig 1998a: 262); Őrtilos (Vig 1998a: 262).

Longitarsus tabidus (Fabricius, 1775) Kaszópuszta (Vig 1998a: 263); Szenta (Vig 1998a: 263).

Longitarsus tristis Weise, 1888 - Siófok (Kaszab 1962a: 325, 1962b: 75).
Altica brevicollis Foudras, 1860 - Barcsi ôsborókás (Vig 1998a: 263); Somogyudvarhely (Vig 1998a: 263).

Altica carduorum Guérin-Méneville, 1858 Potony (Vig 1998a: 263); Vízvár (Vig 1998b).

Altica comivorax Král,1969 - Zamárdi (Kaszab 1962a: 334).

Altica lythry Aubé, 1843 - Barcsi ősborókás (Vig 1998a: 263); Vízvár (Vig 1998a: 263).

Altica heliantheni (Allard,1895) - Siófok

(Kaszab 1962a: 331).

Altica oleracea (Linnaeus, 1758) - Babócsa (Vig 1998b); Vízvár (Vig 1998b).

Altica quercetorum Foudras, 1860 - Barcsi ôsborókás (Vig 1998a: 263).

Hermaophaga mercurialis (Fabricius, 1792) Iharosberény (Vig 1998a: 263).

Batophila fallax Weise, 1888 - Siófok (Kaszab 1962a: 338, 1962b: 90); Zamárdi (Kaszab 1962a: 338, 1962b: 90).

Batophila rubi (Paykull, 1799) - Tótújfalu (Vig 1998a: 263).

Dibolia cynoglossi (Koch, 1803) - Siófok (Kaszab 1962a: 343).

Dibolia depressiuscula Letzner, 1847 Babócsa (Vig 1998b).

Dibolia occultans (Koch, 1803) - Szenta (Vig 1998a: 263).

Chaetocnema aerosa (Letzner, 1846) - Siófok (Kaszab 1962a: 360).

Chaetocnema chlorophana (Duftschmidt, 1825) - Babócsa (Vig 1998b); Bélavár (Vig 1998a: 264); Vízvár (Vig 1998b).

Chaetocnema chlorophana ab. laeta - Siófok (Kaszab 1962a: 352).

Chaetocnema concinna (Marsham, 1802) Babócsa (Vig 1998b); Barcsi ósborókás (Vig 1998a: 264); Darány (Vig 1998a: 264); Vízvár (Vig 1998a: 264).

Chaetocnema conducta (Motschulsky, 1838) Babócsa (Vig 1998b).

Chaetocnema confusa (Boheman, 1851) - Siófok (Kaszab 1962a: 358).

Chaetocnema hortensis (Geoffroy, 1785) Babócsa (Vig 1998b); Barcs (Vig 1998a: 264); Barcsi ősborókás (Vig 1998a: 264); Bélavár (Vig 1998a: 264); Darány (Vig 1998a: 264); Heresznye (Vig 1998b); Vízvár (Vig 1998b).

Chaetocnema laevicollis (Thomson, 1866) Barcsi ősborókás (Vig 1998a: 264); Darány (Vig 1998a: 264); Heresznye (Vig 1998b); Vízvár (Vig 1998b).

Chaetocnema major (Jacquelin du Val, 1825) Siófok (Kaszab 1962a: 352). 
Chaetocnema mannerheimii (Gyllenhal, 1827) -

Barcsi ôsborókás (Vig 1998a: 264).

Chaetocnema semicoerulea (Koch, 1803) ab. femoralis - Siófok (Kaszab 1962a: 353).

Chaetocnema subcoerulea (Kutschera, 1864) Siófok (Kaszab 1962a: 359); Zamárdi (Kaszab 1962a: 359).

Chaetocnema tibialis (Illiger, 1807) - Barcsi ósborókás (Vig I998a: 264).

Lythraria salicariae (Paykull, 1800) - Barcsi ósborókás (Vig 1998a: 264).

Podagrica malvae (Illiger,1807) - pontos lelóhelynélkül (Polinszky 1886:148).

Podagrica fuscicornis (Linnaeus, 1767) chrysomelina - Boglár (Kaszab I 962a: 363).

Podagrica menetriesi (Faldermann, 1837) Bélavár (Vig 1998a: 264); Gyékényes (Vig 1998a: 264); Órtilos (Vig 1998a: 264); Potony (Vig 1998a: 264); Tótújfalu (Vig 1998a: 264).

Podagrica menetriesi ab. csepelensis - Zamárdi (Kaszab 1962a: 364).

Mantura obtusata (Gyllenhal, 1813) - Barcs (Vig 1998a: 264); Barcsi ósborókás (Vig 1998a: 264); Bélavár (Vig 1998a: 264); Darány (Vig 1998a: 264).

Neocrepidodera crassicomis (Faldermann, 1837) - Vízvár (Vig 1998b).

Crepidodera femorata (Gyllenhal, 1813). Siófok (Kaszab 1962a: 374).

Neocrepidodera ferruginea (Scopoli, 1763) Babócsa (Vig 1998b); Barcsi ósborókás (Vig 1998a: 264); Darány (Vig 1998a: 264); Bélavár (Vig 1998a: 264); Örtilos (Vig 1998a: 265); Vízvár (Vig 1998a: 265); Zákány (Vig 1998a: 265).

Neocrepidodera transwersa (Marsham, 1802) Babócsa (Vig 1998b); Barcsi ósborókás (Vig 1998a: 265); Darány (Vig I 998a: 265); Vízvár (Vig 1998a: 265).

Ochrosis ventralis (Illiger, 1807) ab. obscuricollis - Siófok (Kaszab 1962a: 379).

Crepidodera aurata (Marsham, 1802) Babócsa (Vig 1998b); Barcs (Vig 1998a: 265); Barcsi ősborókás (Vig 1998a: 265); Bélavár (Vig 1998a: 265); Darány (Vig 1998a: 265); Órtilos (Vig 1998a: 265); Vízvár (Vig 1998a: 265); Zákány (Vig 1998a: 265).

Crepidodera aurea (Geoffroy, I 785) - Bélavár (Vig 1998a: 265); Órtilos (Vig 1998a: 265); Somogyudvarhely (Vig 1998a: 265); Vízvár (Vig 1998a: 265).

Crepidodera fulvicomis (Fabricius, 1792) Barcsi ösborókás (Vig 1998a: 265).

Crepidodera plutus (Latreille, 1804) - Örtilos (Vig 1998a: 265).
Hippuriphila modeeri (Linnaeus, 1761) - Zákány (Vig 1998a: 265).

Epitrix atropae Foudras, I 860 ab. suturata Siófok (Kaszab 1962a: 386).

Epitrix pubescens (Koch, 1803) - Barcsi ósborókás (Vig 1998a: 265); Darány (Vig 1998a: 265); Vízvár (Vig 1998b).

Psylliodes affinis (Paykull, 1799) - Barcsi ósborókás (Vig 1998a: 265); Órtilos (Vig 1998a: 265); Szenta (Vig 1998a: 265).

Psylliodes chrysocephala (Linnaeus, 1758) Barcsi ősborókás (Vig 1998a: 265); Darány (Vig 1998a: 265); Vízvár (Vig 1998a: 265).

Psylliodes cuprea (Koch, 1803) - Siófok (Kaszab 1962a: 393).

Psylliodes cupreata (Duftschmidt, 1825) Siófok (Kaszab 1962a: 393).

Psylliodes dulcamare (Koch, 1803) - Barcsi ósborókás (Vig 1998a: 265); Szenta (Vig 1998a: 265)

Psylliodes hyoscyami (Linnaeus, 1758) - Siófok (Kaszab 1962a: 395).

Psylliodes illyricus Leonardi \& Gruev, 1993. Siófok (Leonardi \& Gruev, 1993: 16); [=Psylliodes picina] (Kaszab 1962a: 390).

Psylliodes isatidis Heikertinger, 1912 - Siófok (Kaszab 1962a: 393).

Psylliodes kiesenwetteri Kutschera, 1864 - Siófok (Kaszab 1962a: 396, 1962b: 90).

Psylliodes sophiae Heikertinger, 1914 ab. Lichtneckerti - Siófok (Kaszab 1962a: 39l, 1962b: 77).

Psylliodes sophiae ab. nigrivertex - Siófok (Kaszab 1962a: 392).

\section{Hispinae}

Hispa atra Linnaeus, 1767 - Órtilos (Vig 1998a: 265); Vízvár (Vig 1998a: 265).

\section{Cassidinae}

Cassida aurora Weise, 1907 - Siófok (Kaszab 1962a: 413).

Cassida berolinensis Suffrian, 1844 - Siófok (Kaszab 1962a: 410).

Cassida denticollis Suffrian, 1844 - Babócsa (Vig 1998a: 266); Barcsi ósborókás (Vig 1998a: 266); Drávatamási (Vig 1998a: 266); Heresznye (Vig 1998a: 266, 1998b); Potony (Vig 1998a: 266); Vízvár (Vig 1998a: 266).

Cassida fastuosa Schaller, 1783 ab. nigrina Siófok (Kaszab 1962a: 403).

Cassida flaveola Thunberg, 1794 - Babócsa (Vig 1998b); Barcsi ôsborókás (Vig 1998a: 266); Darány (Vig 1998a: 266); Vízvár (Vig 1998b). 
Cassida hemisphaerica Herbst, 1799 - Szenta (Vig 1998a: 266).

Cassida inquinita Brullé, 1832 - Öszöd (Kaszab 1962a: 413).

Cassida lineola Creutzer, 1799 - Siófok (Kaszab 1962a: 410).

Cassida margaritacea Schaller, 1783 - Barcsi ósborókás (Vig 1998a: 266); Bélavár (Vig 1998a: 266); Darány (Vig 1998a: 266); Órtilos (Vig 1998a: 266).

Cassida nebulosa Linnaeus, 1758 - Barcsi ósborókás (Vig 1998a: 266); Vízvár (Vig 1998a: 266).

Cassida nobilis Linnaeus, 1758 - Bolhó (Vig 1998a: 266).

Cassida pannonica Suffrian, 1844 - Babócsa (Vig 1998a: 266); Barcsi ósborókás (Vig 1998a: 266); Darány (Vig 1998a: 266); Örtilos (Vig 1998a: 266).

Cassida prasina Illiger, 1798 - Barcsi ósborókás (Vig 1998a: 266); Gyékényes (Vig 1998a: 266); Ôrtilos (Vig 1998a: 266); Vizvár (Vig 1998b).

Cassida rubiginosa O. F. Müller, 1776 . Babócsa (Vig 1998b); Bolhó (Vig 1998a: 266); Tótújfalu (Vig 1998a: 266); Vízvár (Vig 1998a: 266).

Cassida sanguinolenta O. F. Müller, I776 Babócsa (Vig 1998b); Darány (Vig 1998a: 266).
Cassida stigmatica Suffrian, 1844 - Babócsa (Vig 1998b).

Cassida subferruginea Schrank, 1776 Potony (Vig 1998a: 266).

Cassida vibex Linnaeus, 1767 - Barcsi ôsborókás (Vig 1998a: 266); Bélavár (Vig 1998a: 266); Bolhó (Vig 1998a: 266); Komlósd (Vig 1998a: 266); Örtilos (Vig 1998a: 266); Potony (Vig 1998a: 266).

Cassida piridis Linnaeus, 1758 - Babócsa (Vig 1998b); Bélavár (Vig 1998a: 266); Drávatamási (Vig 1998a: 266); Örtilos (Vig 1998a: 266); Somogyudvarhely (Vig 1998a: 266); Vízvár (Vig 1998a: 266).

Cassida vittata Villers, 1798 - Siófok (Kaszab 1962a: 416).

\section{Bruchidae}

Bruchus luteicornis Illiger, 1794 - Őrtilos (Merkl 1998: 228).

Bruchidius pubicornis Lukjanovich et TerMinassian, 1957 - Siófok (Kaszab 1967: 24).

Spermophagus calystegiae (Lukjanovich et Ter-Minassian, 1957) - Gordisa (Merkl 1998: 228).

1. táblázat: Somogy megyéból ismert Chrysomelidae és Bruchidae fajok száma

\begin{tabular}{|l|c|}
\hline Család & Fajszám \\
\hline Chrysomelidae & 272 \\
\hline Bruchidae & 3 \\
\hline
\end{tabular}

\section{Köszönetnyilvánítás}

A szerző köszönetét fejezi ki Merkl Ottónak a zsizsikadatok közlésének átengedéséért, továbbá Pál Jánosnak, a levélbogarakat ábrázoló festmények megalkotásáért. Jelen publikáció elkészítését a Magyar Tudományos Akadémia Bolyai János Kutatási Ösztöndíja támogatta. 


\section{Irodalom}

GebHARdT, A. 1965: Faunisztikai és ökológiai vizsgálatok a Misina- és Tubestetőn. - A Janus Pannonius Múzeum Évkönyve (1964): 7-29.

Gruev, B. \& MERKL, O. I 992: To the geographic distribution of the Longitarsus pratensis-group (Coleoptera, Chrysomelidae: Alticinae). - Folia ent. hung. (1991), 52: 15-20.

KASZAB, Z. 1962a: Levélbogarak - Chrysomelidae. - In: Magyarország állatvilága, IX: 6 (Fauna Hungariae 63.), Akadémiai Kiadó, Budapest, 416 p.

KaszaB, Z. 1962b: Beiträge zur Kenntnis der Chrysomeliden-Fauna des Karpatenbeckens nebst Beschreibung neuer Formen (Coleoptera). - Folia ent. hung. (S. N.), 15(3): 25-93.

KASZAB, Z. 1967: Zsizsikfélék - Bruchidae. - In: Magyarország Állatvilága, IX: 7 (Fauna Hungariae 84.) Akadémiai Kiadó, Budapest, 34 p.

Kaufmann, E. I914a: Pécs város és Baranya megye bogárfaunája. - „Pécs-Baranyamegyei Múzeum Egyesület" kiadása, Pécs, 95 p.

KaUfmanN, E. 1914b: Képek a Mecsek-hegység bogárvilágából. - A „Mecsek Egyesület” 1913-iki Évkönyve (különlenyomat), 1-35. pp.

KippenberG, H. \& Döberl, M. 1994: 88. Familie: Chrysomelidae. - In: Lohse, G. A. \& Lucht, W. H. (szerk.): Die Käfer Mitteleuropas: 3. Supplementband mit Katalogteil, Goecke \& Evers, Krefeld, 17-142. pp.

KuTHY, D. 1896: Ordo Coleoptera. - In: A Magyar Birodalom Állatvilága - Fauna regni Hungariae, K. M. Termtud. Társulat, Budapest, 213 p.

LeONARDI, C. \& Gruev, B. 1993: Note sistematiche e geonemiche su alcuni Psylliodes del complesso picinus (Marsh.) con descrizione di una nuova specie (Coleoptera, Chrysomelidae). Atti. Soc. Ital. Sci. Nat. Mus. Civ. Stor. Nat. Milano (1992), 133(2): 13-32.

Merku, O. 1998: Data to 46 beetle families (Coleoptera) from the Duna-Dráva National Park, South Hungary. - Dunántúli Dolgozatok, Természettudományi Sorozat 10: 209-232.

PiLLICH, F. 1910-1911: Simontornyán gyúijtött bogaraim jegyzéke I-III. - Rovartani Lapok, 17(10): 154-158, 18(1): 8-10, 18(2): 24-27.

Pillich, F. 1912: Adatok Simontornya bogárfaunájához (Beiträge zur Kaferfauna von Simontornya). - Rovartani Lapok, 19(4-5): 60-66.

Pillich, F. 1914: Aus der Arthropodenwelt Simontornya's. Ein monographischer Beitrag. Druck der Entomologischen Druckerei P. Salchert, Berlin, No. 18., 172 p.

PolinszKY, E. 1886: Adatok Somogymegye bogárfaunájához. - Rovartani lapok 3: 146-148.

REID, C. A. M. 1995: A cladistic analysis of subfamilial relationships in the Chrysomelidae sensu lato (Chrysomeloidea). - In: Pakaluk, J. \& Slipinski, S. A. (szerk.): Biology, phylogeny and classification of Coleoptera: Papers celebrating the $80^{\text {th }}$ birthday of Roy A. Crowson. Museum I Instytut Zoologii PAN, Warsawa, 559-631. pp.

TóTH, L. 1979: A Bakony hegység levélbogár-faunájának alapvetése. - A Veszprém megyei Múzeumok Közleményei, 14: 115-1 18.

UhErkovich, Á. 1978 (szerk.): A Barcsi Ôsborókás élôvilága I. - Dunántúli Dolgozatok, Természettudományi Sorozat (Pécs), 1: 1-151.

UherKovich, Á. 1981 (szerk.): A Barcsi borókás élốvilága II. - Dunántúli Dolgozatok, Természettudományi Sorozat (Pécs), 2: 1-188.

UHERKovich, Á. 1983 (szerk.): A Barcsi borókás élővilága III. - Dunántúli Dolgozatok, Természettudományi Sorozat (Pécs), 3: 1-125.

Uherkovich, Á. 1985 (szerk.): A Barcsi borókás élóvilága IV. - Dunántúli Dolgozatok, Természettudományi Sorozat (Pécs), 5: 1-243.

UherKovich, Á. 1992 (szerk.): A Béda-Karapancsa Tájvédelmi Körzet élôvilága. - Dunántúli Dolgozatok, Természettudományi Sorozat (Pécs), 6: 1-272.

UherKovich, Á. 1995 (szerk.): A Dráva mente állatvilága I. - Dunántúli Dolgozatok, Természettudományi Sorozat (Pécs), 8: 1-210. 
Uherkovich, Á. 1998 (szerk.): A Dráva mente állatvilága II. - Dunántúli Dolgozatok, Természettudományi Sorozat (Pécs), 9: 1-509.

VIERTL, B. 1894: Pécs és környékének bogárfaunája.- In: Ágh T. (szerk.): Emléklapok Pécs sz. kir. város múltjából és jelenéből. - Pécs, 39-61. pp.

VIG, K. 1989: Kártevő földibolha fajok (Phyllotreta spp.) rendszertana, alaktana és életmódja (Coleoptera, Chrysomelidae: Alticinae). - Kandidátusi értekezés (Kézirat), Keszthely-Szombathely, 184 p. + XXXI.

VIG, K. 1996: A Nyugat-magyarországi-peremvidék levélbogárfaunájának alapvetése (Coleoptera: Chrysomelidae sensu lato). - Praenorica, Folia hist. nat., 3: 1-178.

VIG, K. 1998a: A Duna-Dráva Nemzeti Park levélbogár faunája (Coleoptera, Chrysomelidae sensu lato). - Dunántúli Dolgozatok Természetudományi Sorozat, 9: 249-268.

VIG, K. 1998b: Levélbogarak (Coleoptera, Chrysomelidae). ? In: Kondorosy E. (szerk.): Vízvár északi terület általános zoológiai állapotfelmérése. - Kutatási jelentés (Kézirat), Keszthely, 67 p. 


\title{
The chrysomelid and seed weevil fauna of Somogy county (Coleoptera: Chrysomelidae Bruchidae)
}

\author{
KÁROLY VIG
}

The earliest records on the Coleoptera fauna of Somogy county date back to the second half of the $19^{\text {th }}$ century (POLINSZKY I 886). In the middle of the last century, Ferenc Lichtneckert carried out significant field works in the area around Siófok. After his death, his collection was taken to the Hungarian Natural History Museum, Budapest where all the unlabeled insects were given new locality labels marking "Siófok". Although the original labels, made by Lichtneckert, and the new ones of the museum are clearly distinguishable, this fact was ignored by the researchers in later years (KASZAB 1962a, 1962b). Therefore, in the literature of coleopterology, there are several species with the locality of Siófok whose occurrences are doubtful or almost impossible around the town.

The present list of species gives an account of all the taxa, collected by Lichtneckert (e.g. Smaragdina tibialis hungarica Weise, 1895; Cryptocephalus czwalinai Weise, 1882; Cryptocephalus hypochaeridis hypochaeridis (Linnaeus, 1758); Cryptocephalus marginellus Olivier, 1791; Chrysolina hemisphaerica purpurascens (Germar, 1882); Timarchida deubeli Ganglbauer, 1897; Gonioctena interposita (Franz et Palmén, 1950); Luperus viridipennis Germar, 1824; Luperus carniolicus Kiesenwetter, 1861; Psylliodes kiesenwtteri Kutschera, 1864), including the ones whose occurrences are doubtful not only in the area around Siófok, but in some cases, in the entire region of the Carpathian Basin.

In spite the diversity of the habitats of this county, systematic faunistical surveys were carried out only in the last few decades of last century in the Barcs Landscape Protection Area and in the Duna-Dráva National Park. The majority of the data available were the result of these faunistical surveys.

The data provided by the present enumeration are based exclusively on literary references. According to literature data, 27 I chrysomelid taxa and 3 seed weevil species are known from the area of the county.

Due to their rarity, the following chrysomelid taxa are worth mentioning: Macroplea mutica balatonica Székessy, 1941; Donacia antiqua Kunze, 1818; Donacia cinerea Herbst, 1783; Donacia impressa Paykull, 1799; Smaragdina flavicollis (Charpentier, 1825); Pachybrachis sinuatus Mulsant, 1859; Cryptocephalus decemmaculatus (Linnaeus, 1758); Chrysolina eurina (Frivaldszky, 1883); Chrysomela saliceti (Weise, 1884); Phyllotreta tetrastigma (Comolli, 1837); Altica lythry Aubé, 1843; Mantura obtusata (Gyllenhal, 1813).

Since the specimens of Macroplea mutica balatonica Székessy, 1941 used to be collected only on the northern side of Lake Balaton, the recent occurrence of this species on the southern side of the lake needs to be stressed.

Author's address:

Dr. Károly VIG

Natural History Department

Savaria Museum

H-9701 Szombathely

Po. Box 14.

HUNGARY 